\title{
PREDICTION OF SOME PHYSICAL AND DRYING PROPERTIES OF TEREBINTH FRUIT (PISTACIA ATLANTICA L.) USING ARTIFICIAL NEURAL NETWORKS
}

\author{
Mohammad Kaveh, Reza Amiri Chayjan ${ }^{\bowtie}$ \\ Department of Biosystems Engineering, Faculty of Agriculture, Bu-Ali Sina University, Hamedan, Iran
}

\begin{abstract}
Background. Drying of terebinth fruit was conducted to provide microbiological stability, reduce product deterioration due to chemical reactions, facilitate storage and lower transportation costs. Because terebinth fruit is susceptible to heat, the selection of a suitable drying technology is a challenging task. Artificial neural networks (ANNs) are used as a nonlinear mapping structures for modelling and prediction of some physical and drying properties of terebinth fruit.

Material and methods. Drying characteristics of terebinth fruit with an initial moisture content of 1.16 (d.b.) was studied in an infrared fluidized bed dryer. Different levels of air temperatures $\left(40,55\right.$ and $\left.70^{\circ} \mathrm{C}\right)$, air velocities $(0.93,1.76$ and $2.6 \mathrm{~m} / \mathrm{s})$ and infrared (IR) radiation powers $(500,1000$ and $1500 \mathrm{~W})$ were applied. In the present study, the application of Artificial Neural Network (ANN) for predicting the drying moisture diffusivity, energy consumption, shrinkage, drying rate and moisture ratio (output parameter for ANN modelling) was investigated. Air temperature, air velocity, IR radiation and drying time were considered as input parameters.

Results. The results revealed that to predict drying rate and moisture ratio a network with the TANSIG-LOGSIG-TANSIG transfer function and Levenberg-Marquardt (LM) training algorithm made the most accurate predictions for the terebinth fruit drying. The best results for ANN at predications were $R^{2}=0.9678$ for drying rate, $R^{2}=0.9945$ for moisture ratio, $R^{2}=0.9857$ for moisture diffusivity and $R^{2}=0.9893$ for energy consumption.

Conclusion. Results indicated that artificial neural network can be used as an alternative approach for modelling and predicting of terebinth fruit drying parameters with high correlation. Also ANN can be used in optimization of the process.
\end{abstract}

Key words: terebinth, drying, moisture diffusivity, infrared, artificial neural network

\section{INTRODUCTION}

Terebinth (Pistacia atlantica L.) is an ancient and long life tree with about $5 \mathrm{~m}$ height. Ripening time of the terebnith fruit is May and June. Terebinth grows in many areas of the Iranian plateau. Three Iranian sub-species of terebinth fruit are Mutika, Kurdika and Kabulika. Each of species grows in different regions of the country. Terebinth fruit is small, spheroid and dark green. It is similar to pistachio but much smaller. Terebinth fruit is used to flavour buttermilk and animal oils and also used to make pickles [Amiri Chayjan and Kaveh 2013]. Moisture content of terebnith fruit in harvesting time is about 1.16 (d.b.) causing microbial 
spoilage soon after harvest. Terebinth fruit have medical applications such as: reducing blood fat, elevating and strengthening the liver and spleen.

Drying is an important process for handling raw materials in order to prolong its shelf life, as the drying process inhibits enzymatic degradation and limits microbial growth [Ahrne et al. 2007]. Infrared radiation has been successfully applied in the drying of foods and agricultural products [Siriamornpun et al. 2012], since the main components of these products have their principal absorption bands in the infrared radiation region [Meeso 2008]. Unlike hot air drying, infrared radiation generates internal heating through molecular vibration of the material, bringing about excited vibration when molecules absorb the radiation of certain wavelengths and energy [Siriamornpun et al. 2012]. Therefore, the dried food absorbs the electromagnetic wave energy directly with reduced energy loss. Many workers studied IR drying as a potential method to obtain high quality dried fruits, vegetables and grains [Ruiz Celma et al. 2009, Khir et al. 2011, Dondee et al. 2011, Ponkham et al. 2012].

In food processing, nonlinear models are more popular due to nonlinear behaviour and variability of foodstuffs. Moreover, product processing involves many fluctuations in process conditions greatly depend on the skill and experience of operators. Therefore, artificial neural network (ANN) has gained momentum for process modelling and control. ANN is recognised as a good tool for static modelling because it is capable of handling complex systems with nonlinearities and interactions between decision variables, has an ability to learn the solution of problems from a set of experimental data and does not require physical parameters of models. ANN models were constructed by many interconnecting nonlinear computational elements, known as neurons or nodes, operating in parallel and arranging in patterns similar to biological networks [Mohebbi et al. 2011, Amiri Chayjan et al. 2012 a].

Quantification of relationships between inputs and outputs of a complex process such as infrared drying operation using mathematical, statistical and analytical methods is much more difficult. It is worth noting that ANNs provide the potential to identify and classify network activity based on limited, incomplete, noisy, dynamic and nonlinear data sources [Aghbashlo et al. 2012].
Several studies have been carried out to identify complex and nonlinear drying systems and process behaviours using ANNs [Erenturk and Erenturk 2007, Chegini et al. 2008, Omid et al. 2009, Khoshhal et al. 2010, Aghbashlo et al. 2011, Niamnuy et al. 2012].

No study has been reported about effective moisture diffusivity, energy consumption, shrinkage, drying rate and moisture ratio of terebinth fruit by ANN method. The main goals of this study were artificial neural network modelling effective moisture diffusivity, specific energy consumption, shrinkage, drying rate and moisture ratio at infrared drying of terebinth fruit.

\section{MATERIAL AND METHODS}

\section{Sample preparation}

Fresh terebinth fruit supplied from Sardasht forests, west Azerbaijan, Iran. To carry out the drying tests the material was kept at refrigerator temperature $3 \pm 1^{\circ} \mathrm{C}$. Initial moisture content of terebinth fruit was determined by oven method, at a temperature of $70 \pm 1^{\circ} \mathrm{C}$ for 24 hours [Doymaz 2005]. The initial moisture content of the seed was 1.16 (\%d.b.). During two weeks after storage, all drying experiments were conducted.

\section{Drying equipment}

Three experimental points of drying were selected using fluidization curve (Fig. 1). At first, pressure drop of terebinth fruit was determined at different air flow

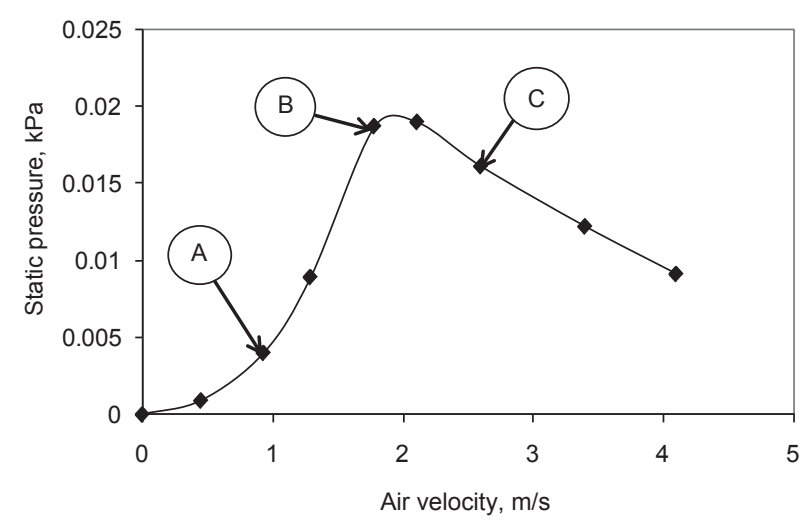

Fig. 1. Fluidization curve of terebinth fruit and selected point for modelling: A - fix bed $(0.93 \mathrm{~m} / \mathrm{s}), \mathrm{B}$ - semi fluid bed $(1.76 \mathrm{~m} / \mathrm{s}), \mathrm{C}-$ fluid bed $(2.6 \mathrm{~m} / \mathrm{s})$ 


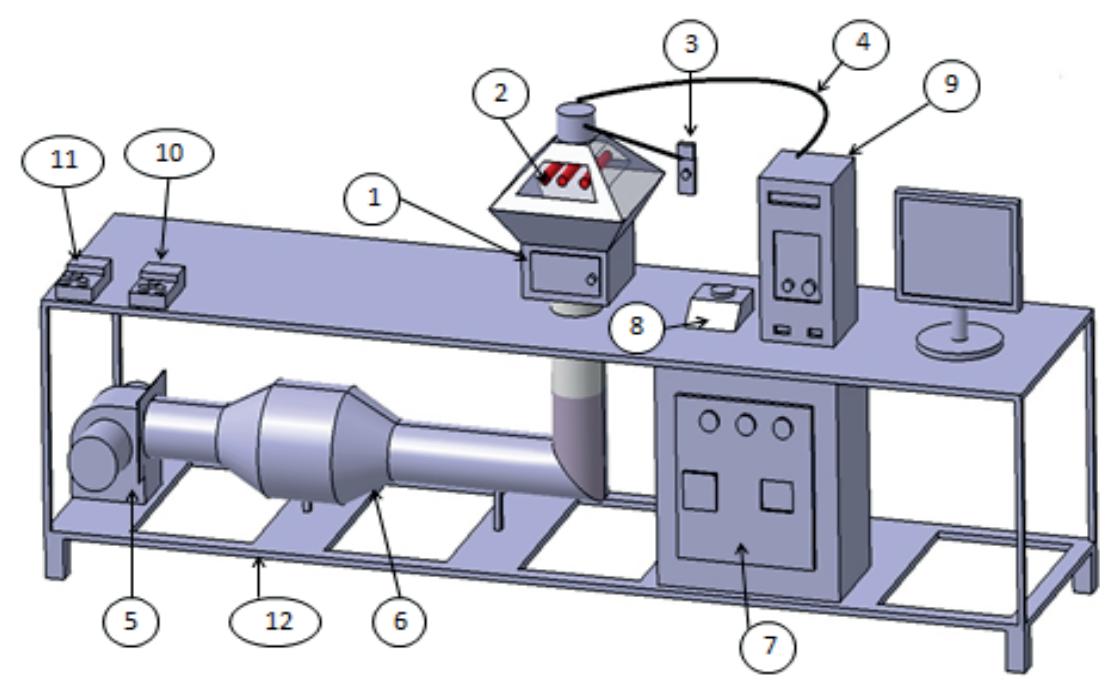

Fig. 2. Schematic diagram of laboratory scale infrared-fluidized bed dryer: 1 - drying chamber, 2 - infrared lamp, 3 - thermocouple, 4 - air velocity sensor, 5 - fan and electrical motor, 6 - electrical heater, 7 - inverter and thermostat, 8 - precision balance, 9 - computer, 10 - thermometer, 11 - psychrometer, 12 - chassis

velocities. Fan speed was gradually increased using an inverter (Vincker VSD2) and parameters of air velocity and pressure drop were recorded using a multifunction measurement device (Standard ST-8897, made in China). It consist a vane type digital anemometer with $\pm 0.1 \mathrm{~m} / \mathrm{s}$ accuracy and a differential manometer with $\pm 0.1 \mathrm{~Pa}$ accuracy. Drying experiments were conducted using a laboratory infrared-fluidized bed dryer (Fig. 2).

Maximum static pressure drop (point B in Figure 1) in fluidization curve of terebinth fruit is known as minimum fluidization or semi fluid bed. An experimental point in fixed bed domain was selected with air velocity about $0.93 \mathrm{~m} / \mathrm{s}$ (point A in Figure 1), also experimental point $C$ with air velocity about $2.6 \mathrm{~m} / \mathrm{s}$ was selected as fluid bed condition. A laboratory fluid bed dryer was used to perform the drying experiments (Fig. 2). Three bed conditions (fix bed at $0.93 \mathrm{~m} / \mathrm{s}$, semi fluid bed at $1.76 \mathrm{~m} / \mathrm{s}$ and fluid bed at $2.6 \mathrm{~m} / \mathrm{s}$ ) and three air temperatures of 40,55 , and $70^{\circ} \mathrm{C}$ were applied in the experiments. Also, three infrared power of 500, 1000 and $1500 \mathrm{~W}$ were used in the experiments. About $30 \mathrm{~g}$ of terebinth fruit after weighing were uniformly spread in a perforated plate and kept inside the dryer. Drying time was considered as the time required reducing the moisture content of the product to 0.2 (d.b.). Drying experiments were conducted in three replications.

\section{Theoretical principle}

During the drying period, weight measurement has been made once every half an hour. At the end of two consecutive attempts, absolute dry weight has been considered to be achieved with the condition that the weight changed less than $1 \%$. Initial moisture contents (dry basis) of the terebinth fruit have been calculated with the following equation [Menlik et al. 2010]:

$$
M C_{d b}=\frac{M_{i}-M_{a}}{M_{a}}
$$

where $M C_{d b}$ is the moisture contents (d.b.), $M_{a}$ is the dry weight $(\mathrm{kg}), M_{i}$ is the wet weight $(\mathrm{kg})$.

\section{Drying rate}

Drying rate can be defined as the moisture content variation with time and calculated by using the following equation [Xiao et al. 2010]:

$$
D R=\frac{\left(M_{\mathrm{t}+\mathrm{dt}}-M_{t}\right)}{d t}
$$


where $M_{t}$ and $M_{\mathrm{t}+\mathrm{dt}}$ are the moisture content at drying time of $t$ and $t+d t$, respectively.

\section{Effective moisture diffusivity}

Second low of Fick in diffusion with sphere geometry is used for computing of effective moisture diffusivity. The seed shrinkage was assumed after drying process as negligible and distribution of initial moisture as uniform. Fick's equation for computing effective moisture diffusivity of terebinth is as follows [Nuthong et al. 2011]:

$$
M R=\frac{M_{x}-M_{e}}{M_{y}-M_{e}}=\frac{6}{\pi^{2}} \sum_{n=1}^{\infty} \frac{1}{n^{2}} \exp \left(\frac{-D_{\mathrm{eff}} n^{2} \pi^{2} t}{R^{2}}\right)
$$

where $M R$ is the moisture ratio, $M_{x}$ is the moisture content at any time (\%d.b.), $M_{e}$ is the equilibrium moisture content (\%d.b.), $M_{y}$ is the initial moisture content (\%d.b.), $n$ is the number of terms taken into consideration, $t$ is the drying time (s), $D_{\text {eff }}$ is the effective moisture diffusivity $\left(\mathrm{m}^{2} / \mathrm{s}\right)$ and $R$ is the radius of terebinth (m).

The equilibrium moisture content $\left(M_{e}\right)$ is negligible related to the other moisture contents. Taking the natural logarithm of both sides of Eq. (2), the following equation is obtained [Das et al. 2009]:

$$
\ln (M R)=\ln \left(\frac{M_{x}}{M_{y}}\right)=\ln \left(\frac{6}{\pi^{2}}\right)-\left(\frac{D_{\mathrm{eff}} \pi^{2} t}{R^{2}}\right)
$$

The effective diffusivity $\left(D_{\text {eff }}\right)$, was determined from the slope of the $\ln \left(\frac{M_{x}-M_{e}}{M_{y}-M_{e}}\right)$ versus time plot.

\section{Specific energy consumption}

Specific energy consumption $(S E)$ for terebinth drying was obtained using the following thermodynamic equation [Amiri Chayjan et al. 2012 b]:

$$
S E=Q t\left(C_{p a}+C_{p v} h_{a}\right) \frac{\left(T_{i n}-T_{a m}\right)}{m_{v} V_{h}}
$$

where $S E$ is specific energy consumption $(\mathrm{kJ} / \mathrm{kg}), C_{P_{V}}$ and $C_{P a}$ are specific heat capacity of vapor and air, respectively, (1004.16 and $\left.1828.8 \mathrm{~J} / \mathrm{kg} \cdot{ }^{\circ} \mathrm{C}\right), Q$ is the inlet air to drying chamber $\left(\mathrm{m}^{3} / \mathrm{min}\right)$, $t$ is the total drying time (min), $h_{a}$ is absolute air humidity $\left(\mathrm{kg}_{\text {vapor }} / \mathrm{kg}_{\text {dry air }}\right.$ ),
$T_{i n}$ and $T_{a m}$ are inlet air to drying chamber and ambient air temperatures, respectively, $\left({ }^{\circ} \mathrm{C}\right), m_{v}$ is mass of removal water $(\mathrm{kg})$ and $V_{h}$ is specific air volume $\left(\mathrm{m}^{3} / \mathrm{kg}\right)$.

\section{Shrinkage}

Based on measurements of the volume of material, shrinkage was calculated using the following equation [Nowacka et al. 2012]:

$$
S_{a}=\left(1-\frac{V_{1}}{V_{0}}\right) \times 100
$$

where $S_{a}$ is the shrinkage (\%), $V_{1}$ is the final volume of the dried material $\left(\mathrm{m}^{3}\right)$ and $V_{0}$ is the volume of before drying $\left(\mathrm{m}^{3}\right)$.

\section{Artificial neural networks modelling}

The used neural network in this study is shown in Figure 3. A multilayer perceptron (MLP) neural network with different hidden layers (one and two) was trained and tested. MLP is a layered feed forward back propagation (FFBP) and cascade forward back propagation (CFBP) network typically trained with static back propagation. Its main advantage is easy use and approximation of any input/output parameters. Among the developed networks with different hidden layers, one hidden layer MLP neural network has presented the best results. Therefore, it was determined that one hidden layer ANN with appropriate error minimization algorithms and transfer function and with a sufficient number of hidden neurons and training epochs was capable of approximating exegetic parameters of terebinth fruit drying process.

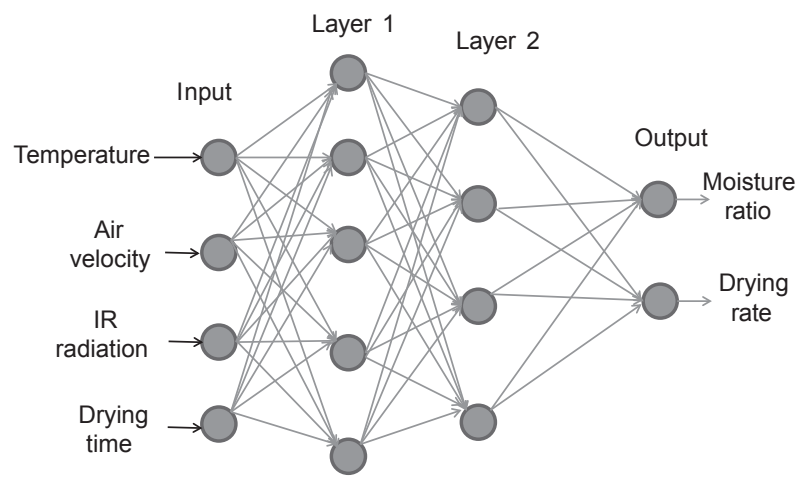

Fig. 3. Schematic structure of the MLP ANN 
The parameters of air temperature, air velocity and IR radiation were used as the inputs, whereas the three parameters of energy consumption, moisture diffusivity and shrinkage were the outputs. Also in another ANN setup modelling, the coefficients of air temperature, air velocity, IR radiation and drying time were used as the inputs, whereas the two parameters drying rate and moisture ratio were the outputs. The neuron number in the first hidden layer varied from 2 to 10 . Also, the number of neurons in the second hidden layer was varied from 2 to 10 . Input variable levels and boundaries are presented in (Tables 1 and 2).

As shown in Figure 3, this type of ANN is a supervised network because it requires a desired output in order to learn. The goal of MLP ANN is to establish a model that accurately maps the input/output relationships using experimental data so that the model can then be used to produce the output when the desired output is unseen. The MLP ANN learns using a back propagation algorithm i.e., the input data is repeatedly

Table 1. Input parameters for artificial neural networks and their boundaries for prediction of effective moisture diffusivity, specific energy consumption and shrinkage of terebinth fruit

\begin{tabular}{lccc}
\hline \multicolumn{1}{c}{ Parameters } & Maximum & Minimum & $\begin{array}{c}\text { Number of } \\
\text { levels }\end{array}$ \\
\hline Air temperature, ${ }^{\circ} \mathrm{C}$ & 70 & 40 & 3 \\
Air velocity, m/s & 2.60 & 0.93 & 3 \\
IR radiation, W & 1500 & 500 & 3 \\
\hline
\end{tabular}

Table 2. Input parameters for artificial neural networks and their boundaries for prediction of drying rate and moisture ratio of terebinth fruit

\begin{tabular}{lccc}
\hline \multicolumn{1}{c}{ Parameters } & Maximum & Minimum & $\begin{array}{c}\text { Number of } \\
\text { levels }\end{array}$ \\
\hline Air temperature, ${ }^{\circ} \mathrm{C}$ & 70 & 40 & 3 \\
Air velocity, m/s & 2.60 & 0.93 & 3 \\
IR radiation, W & 1500 & 500 & 3 \\
Drying time, min & 3 & 650 & - \\
\hline
\end{tabular}

presented to the ANN and the error is calculated for each presentation by comparing the output of the neural network with the desired output. Then, the computed error is fed back or back propagated to the ANN to adjust the weights [Jha 2007].

The effect of various error minimization algorithms including Bayesian regulation (BR) and Levenberg-Marquardt (LM) on ANN performance were investigated. Different transfer functions including hyperbolic tangent sigmoid (tansig), logarithmic sigmoid (logsig), linear (purelin) transfer functions were utilized for determination of neuron output. After using appropriate learning algorithm and transfer function, the effect of neuron number and training epochs were investigated on ANN performance. To develop a statistically model, networks were trained three times and the best values were recorded for each parameter [Aghbashlo et al. 2012]. Data analysis was accomplished using neural network toolbox (ver. 5) of Matlab software.

Three transfer functions were employed to achieve the optimized network structure [Demuth et al. 2007]:

$$
\begin{aligned}
& Y_{j}=X_{j} \\
& Y_{j}=\frac{2}{\left(1+\exp \left(2 X_{j}\right)\right)-1} \quad(\text { TANRELIN }) \\
& Y_{j}=\frac{1}{1+\exp \left(-X_{j}\right)} \quad(\text { LOGSIG })
\end{aligned}
$$

where $X_{j}$ is calculated as follow:

$$
X_{j}=\sum_{i=1}^{m} W_{i j} \times Y_{i}+b_{j}
$$

where $m$ is the number of output layer neurons, $W_{i j}$ is the weight of between $i$-th and $j$-th layers, $Y_{i}$ is the $j$-th output neuron, $X_{j}$ is the $j$-th input neuron, $b_{j}$ is the bias of $j$-th neuron for FFNN and CFNN networks.

\section{Selection of optimal ANN}

About $75 \%$ of the experimental data were separated for network training to find suitable structure. The mean absolute error $(M A E)$, standard deviation mean absolute error $\left(S D_{\mathrm{MAE}}\right)$, mean square error (MSE) and coefficient of determination $\left(R^{2}\right)$ were used to compare the performance of different ANN models and were calculated as follow [Madadlou et al. 2009]: 


$$
\begin{gathered}
M S E=\frac{1}{m q} \sum_{p=1}^{m} \sum_{i=1}^{q}\left(S_{i p}-T_{i p}\right)^{2} \\
R^{2}=1-\frac{\sum_{k=1}^{m}\left[S_{k}-T_{k}\right]}{\sum_{k=1}^{m}\left[S_{k}-\frac{\sum_{k=1}^{n} S_{k}}{n}\right]} \\
M A E=\frac{100}{n} \sum_{k=1}^{m} \mid \frac{S_{k}-T_{k} \mid}{T_{k} \mid} \\
S D_{\mathrm{MAE}}=\sqrt{\frac{\sum_{k=1}^{n}\left(\left|\frac{S_{k}-T_{k}}{T_{k}}\right|-\left|\frac{S_{k}-T_{k}}{T_{k}}\right|\right)}{n-1}}
\end{gathered}
$$

where $S_{i p}$ is the network output in $i$-th neuron and $p$-th pattern, $T_{i p}$ is the target output at $i$-th neuron and $p$-th pattern, $q$ is the number of output neurons, $m$ is the number of training patterns, $S_{k}$ is the network output for $k$-th pattern, $T_{k}$ is the target output for $k$-th pattern, $n$ is the number of training patterns. To increase processing velocity and accuracy of network, input and output data were normalized at domain of $[0,1]$.

\section{RESULTS AND DISCUSSION}

\section{Drying rate}

Figure 4 showed that the drying rate versus drying time of the terebinth samples at drying temperatures 40 , 55 and $70^{\circ} \mathrm{C}$ and IR radiation 500,1000 and $1500 \mathrm{~W}$. After an initial period of sample heating, the drying rate reaches its maximum value, and then the drying product continued at the falling rate period. The mass transfer process takes place initially at the surface of the samples, and continues relevance at subsequent stages. The moisture diffusion becomes the most important factor. However, the three different drying periods observed during the experiment performed at $70^{\circ} \mathrm{C}, 2.6 \mathrm{~m} / \mathrm{s}$ and $1500 \mathrm{~W}$, are an exception to such tendency: an initial heating period (for approximately $180 \mathrm{~s}$ ) was followed by a constant rate period (up to $2100 \mathrm{~s}$ ), and finally by the falling rate period. These experimental results are similar to some others published in the literature, relating to drying experiments concerning vegetables and agricultural products; for instance grape [Ruiz Celma et al. 2009], pomegranate [Mundada et al. 2010], barley [Markowski et al. 2010] and banana [Thuwapanichayanan et al. 2011].

\section{Effective moisture diffusivity}

Table 3 shows the changes of effective moisture diffusivity with IR radiation, air velocity and air temperatures. The higher drying temperature and IR radiation can accelerate the water molecules present in the banana to evaporate faster, thus providing a faster decrease of the material moisture content and the corresponding higher value of effective moisture diffusivity. The results obtained have shown that the isothermal condition was established immediately and maintained throughout drying. Therefore, with negligible sample shrinkage and uniform initial moisture distribution as well as constant moisture diffusivity assumptions, the mathematical solution of Fick's second law for diffusion Eq. (4) was suitable for determining the $D_{\text {eff }}$ The calculated values of $D_{\text {eff }}$ for terebinth drying were $6.2 \cdot 10^{-11}-7.3 \cdot 10^{-10} \mathrm{~m}^{2} / \mathrm{s}$. The values of $D_{\text {eff }}$ increased greatly with increasing temperature and IR radiation and were in the suitable general range of $10^{-11}-10^{-9} \mathrm{~m}^{2} / \mathrm{s}$ for biomass [Chen et al. 2012].

\section{Specific energy consumption}

The specific energy consumption $(S E)$ for drying of terebinth fruit was calculated using Eq. (5). Table 3 shows the computed values of $S E$ for terebinth fruit. It was observed that for all bed conditions, the $S E$ was decreased as drying air temperature was increased. Increasing air velocity cause intensive increase in $S E$. Maximum value of $S E(7077.24 \mathrm{MJ} / \mathrm{kg})$ obtained at fluid bed condition with air velocity of $2.6 \mathrm{~m} / \mathrm{s}$, air temperature of $40^{\circ} \mathrm{C}$ and IR radiation $500 \mathrm{~W}$, while the minimum value of $S E(1162.03 \mathrm{MJ} / \mathrm{kg})$ calculated at fix bed condition with air velocity of $0.93 \mathrm{~m} / \mathrm{s}$ and air temperature of $70^{\circ} \mathrm{C}$ and IR radiation $1500 \mathrm{~W}$. Results indicated that increasing in drying time affect $S E$ inversely. In other words, lower temperature caused lower mass transfer from the fruit. As a result, drying time was increased, so energy consumption was increased. With increasing in IR radiation, the consumed heat was strongly increased and $S E$ was therefore decreased. Similar effects have been reported for corn [Amiri Chayjan et al. 2011] and tomato [Ruiz Celma et al. 2012]. 
Kaveh M., Chayjan R.A., 2014. Prediction of some physical and drying properties of terebinth fruit (Pistacia atlantica L.) using Artificial Neural Networks. Acta Sci. Pol., Technol. Aliment. 13(1), 65-78.
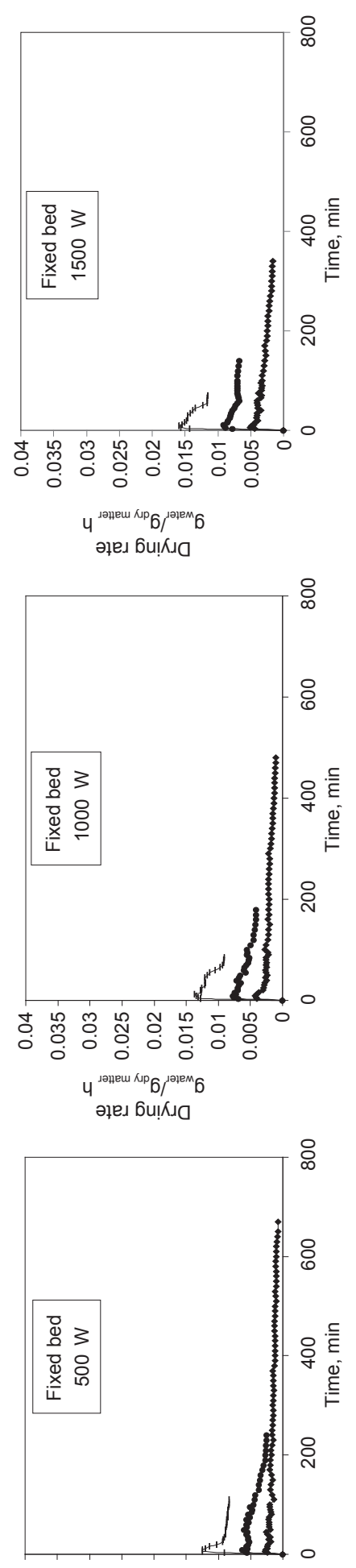

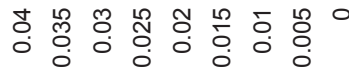

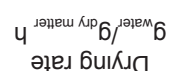
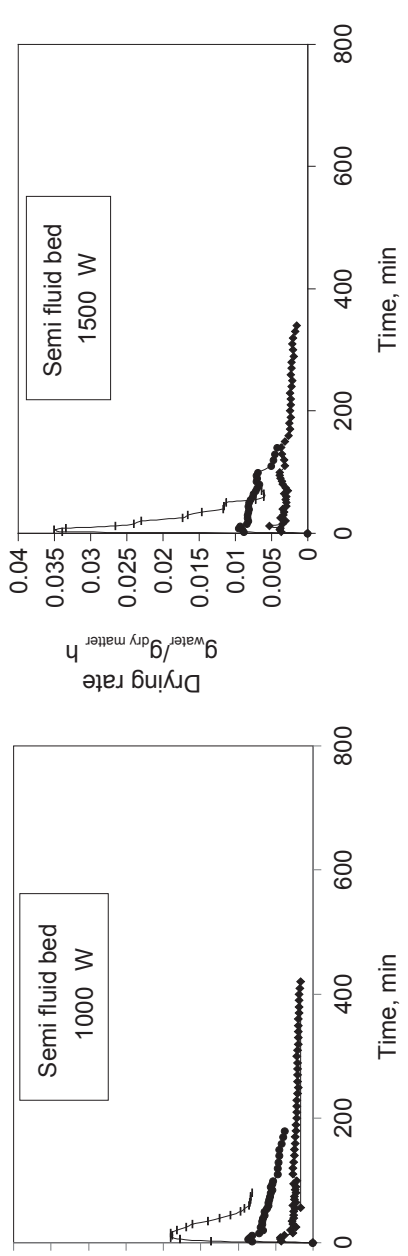

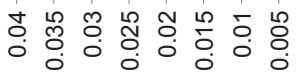

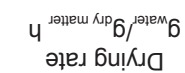

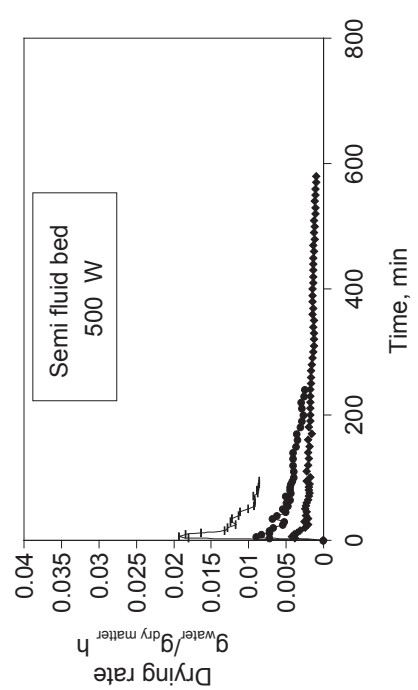

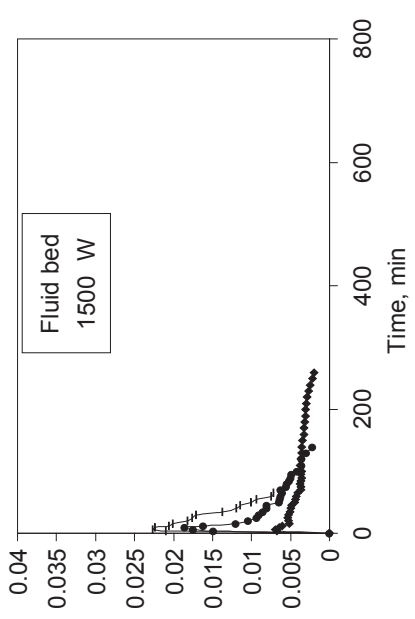

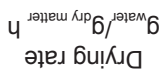

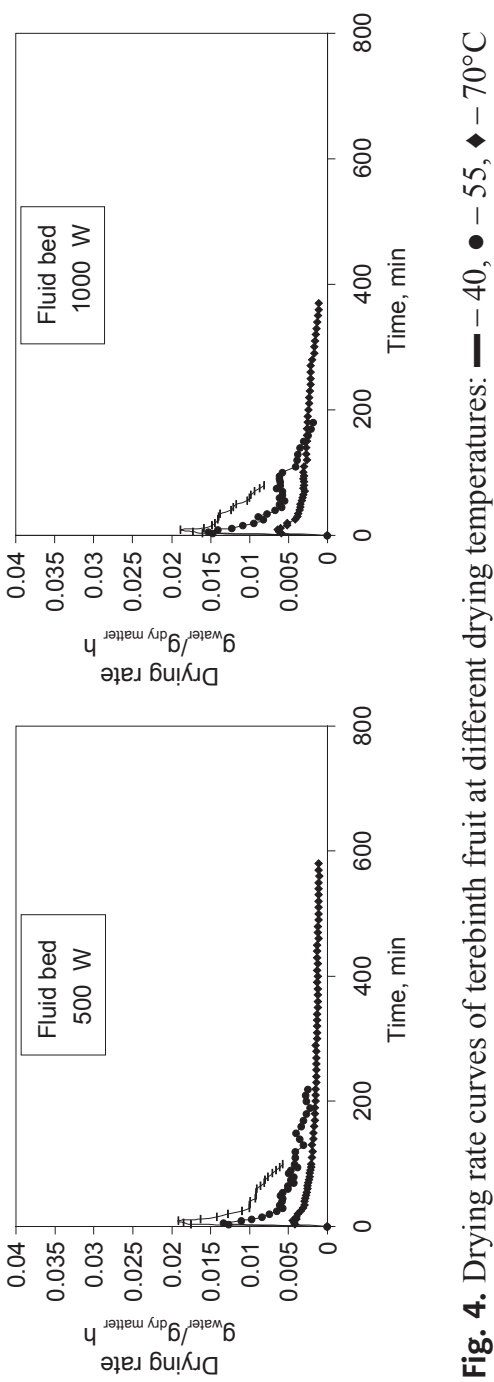


Kaveh M., Chayjan R.A., 2014. Prediction of some physical and drying properties of terebinth fruit (Pistacia atlantica L.) using Artificial Neural Networks. Acta Sci. Pol., Technol. Aliment. 13(1), 65-78.

Table 3. Effective diffusivity values $\left(\mathrm{m}^{2} / \mathrm{s}\right)$ and energy consumption $(\mathrm{kJ} / \mathrm{mol})$ for drying of terebinth fruit

\begin{tabular}{ccccccc}
\hline & \multicolumn{2}{c}{ Fix bed $(0.93 \mathrm{~m} / \mathrm{s})$} & \multicolumn{2}{c}{ Semi fluid bed $(1.76 \mathrm{~m} / \mathrm{s})$} & \multicolumn{2}{c}{ Fluid bed $(2.6 \mathrm{~m} / \mathrm{s})$} \\
\cline { 2 - 7 }- IR radiation, $\mathrm{W}$ & $\begin{array}{c}D_{\text {eff }} \\
\mathrm{m}^{2} / \mathrm{s}\end{array}$ & $\begin{array}{c}S E \\
\mathrm{~kJ} / \mathrm{mol}\end{array}$ & $\begin{array}{c}D_{\text {eff }} \\
\mathrm{m}^{2} / \mathrm{s}\end{array}$ & $\begin{array}{c}S E \\
\mathrm{~kJ} / \mathrm{mol}\end{array}$ & $\begin{array}{c}D_{\text {eff }} \\
\mathrm{m}^{2} / \mathrm{s}\end{array}$ & $\begin{array}{c}S E \\
\mathrm{~kJ} / \mathrm{mol}\end{array}$ \\
\hline $40-500$ & $6.2 \times 10^{-11}$ & 2455.57 & $6.9 \times 10^{-11}$ & 4074.43 & $6.4 \times 10^{-11}$ & 7077.04 \\
$55-500$ & $1.8 \times 10^{-10}$ & 2025.69 & $1.7 \times 10^{-10}$ & 3916.73 & $1.9 \times 10^{-10}$ & 5205.12 \\
$70-500$ & $4.0 \times 10^{-10}$ & 1395.15 & $5.0 \times 10^{-10}$ & 2434.70 & $4.2 \times 10^{-10}$ & 3867.25 \\
$40-1000$ & $8.3 \times 10^{-11}$ & 2387.82 & $9.6 \times 10^{-11}$ & 4071.20 & $1.1 \times 10^{-10}$ & 6771.99 \\
$55-1000$ & $2.2 \times 10^{-10}$ & 1749.14 & $2.5 \times 10^{-10}$ & 3335.43 & $2.5 \times 10^{-10}$ & 4957.02 \\
$70-1000$ & $4.8 \times 10^{-10}$ & 1230.46 & $6.7 \times 10^{-10}$ & 2291.25 & $5.9 \times 10^{-10}$ & 6313.19 \\
$40-1500$ & $1.1 \times 10^{-10}$ & 2328.38 & $1.3 \times 10^{-10}$ & 3954.85 & $1.6 \times 10^{-10}$ & 6516.52 \\
$55-1500$ & $2.8 \times 10^{-10}$ & 1719.55 & $3.1 \times 10^{-10}$ & 3206.32 & $3.4 \times 10^{-10}$ & 4674.52 \\
$70-1500$ & $6.2 \times 10^{-10}$ & 1162.03 & $7.2 \times 10^{-10}$ & 2206.95 & $7.3 \times 10^{-10}$ & 3427.45 \\
\hline
\end{tabular}

\section{Shrinkage}

Table 4 shows variations of the $\left(1-\frac{V_{1}}{V_{0}}\right)$ versus

IR radiation at different air temperatures of 40,55 and $70^{\circ} \mathrm{C}$. The results indicated that by increasing air temperature and IR radiation, the seed shrinkage was increased. Maximum shrinkage $(23.21 \%)$ was calculated at air velocity of $2.6 \mathrm{~m} / \mathrm{s}$, air temperature of $70^{\circ} \mathrm{C}$ and IR radiation $1500 \mathrm{~W}$, respectively. The lowest shrinkage value $(16.43 \%)$ was achieved at air velocity of $0.93 \mathrm{~m} / \mathrm{s}$, air temperature of $40^{\circ} \mathrm{C}$ and IR radiation of $500 \mathrm{~W}$. Accordingly with increasing air temperature, shrinkage was increased. The highest shrinkage value was calculated at the highest temperature $\left(70^{\circ} \mathrm{C}\right)$ level. Also the terebinth fruit shrinkage increased with increasing air velocity and IR radiation. More shrinkage at higher temperatures and IR radiation is due to faster mass transfer, so the created free space causing tension in the terebinth tissue and therefore product becomes more wrinkled. Similar results have been obtained for spirulina [Dissa et al. 2010], pineapple [Ponkham et al. 2012] and papaya [Kurozawa et al. 2012]. Shrinkage value of terebinth fruit under convective drying was predicted by the following linear equation:

$$
\begin{gathered}
S_{a}=0.74 v+0.12 T_{i n}+0.001 I R+9.836 \\
R^{2}=0.9440
\end{gathered}
$$

where: $v$ is the air velocity $(\mathrm{m} / \mathrm{s})$ and $I R$ is the infrared radiation power $(\mathrm{W})$. The effects of all three input parameters on shrinkage were significant. But the effect of air velocity was more the other parameters. This is because of air velocity role in the start of drying process and increasing the cell stresses after surface evaporation.

Table 4. Shrinkage values (\%) for drying of terebinth fruit

\begin{tabular}{cccc}
\hline $\begin{array}{c}\text { Temperature, }{ }^{\circ} \mathrm{C} \\
- \text { IR radiation, W }\end{array}$ & $\begin{array}{c}\text { Fix bed } \\
(0.93 \mathrm{~m} / \mathrm{s})\end{array}$ & $\begin{array}{c}\text { Semi fluid } \\
\text { bed } \\
(1.76 \mathrm{~m} / \mathrm{s})\end{array}$ & $\begin{array}{c}\text { Fluid bed } \\
(2.6 \mathrm{~m} / \mathrm{s})\end{array}$ \\
\hline $40-500$ & 16.43 & 17.32 & 19.07 \\
$55-500$ & 18.74 & 19.00 & 21.55 \\
$70-500$ & 20.22 & 21.01 & 22.71 \\
$40-1000$ & 17.39 & 17.79 & 19.07 \\
$55-1000$ & 19.40 & 19.58 & 21.55 \\
$70-1000$ & 20.70 & 21.89 & 22.71 \\
$40-1500$ & 18.07 & 18.39 & 20.42 \\
$55-1500$ & 19.90 & 20.05 & 22.33 \\
$70-1500$ & 21.14 & 22.86 & 23.21 \\
\hline
\end{tabular}




\section{Artificial Neural Networks modelling}

Various feed-forward and cascade forward ANNs were trained using 50 patterns with back propagation algorithm for creating nonlinear mapping between input parameters (air velocity, air temperature, IR radiation and drying time) and output parameters (effective moisture diffusivity, specific energy consumption, shrinkage, drying rate and moisture ratio). Optimal number of hidden neurons in hidden layers was determined under 3-x-y-1 and 4-x-y-2 architectures. At the first, the number of hidden neurons was chosen equal to one-half the total number of inputs plus outputs. Then the number of nodes was increased and decreased by an increment of 3 in each step to improve the model performance.
Based on the MSE of the training and testing, it was found that compared to the 3-layer ANN models, almost 4-layer models produced better performance. With increasing of own hidden layer (with 3 neurons) to network, MSE of network training increased individually, but with more increasing of the number of neurons, the training's MSE of network decreased. This proved that increasing the number of hidden layers increased the modelling precision and reduced the prediction problem.

In feed forward back propagation (FFBP) networks, the hidden neurons number determines how well a dataset can be learned. Too many hidden neurons will lead to memorize the dataset, and therefore it is not able to generalize the input/output relationship.

Table 5. Best selected topologies including training algorithm, different layers and neurons for FFBP and CFBP for moisture diffusivity of terebinth fruit

\begin{tabular}{|c|c|c|c|c|c|c|c|c|}
\hline Network & $\begin{array}{l}\text { Training } \\
\text { algorithm }\end{array}$ & Threshold function & $\begin{array}{l}\text { Number of } \\
\text { layers } \\
\text { and neurons }\end{array}$ & $M S E$ & $R^{2}$ & $M A E$ & $S D_{\mathrm{MAE}}$ & Epoch \\
\hline \multirow[t]{4}{*}{ FFBP } & LM & TANSIG & $3-6-3-1$ & 0.00032 & 0.9857 & $1.64 \times 10^{-11}$ & $1.15 \times 10^{-11}$ & 11 \\
\hline & & TANSIG-PURELIN-PURELIN & $3-3-4-1$ & 0.00249 & 0.9691 & $6.56 \times 10^{-11}$ & $5.13 \times 10^{-11}$ & 11 \\
\hline & BR & TANSIG & $3-5-2-1$ & 0.00090 & 0.9783 & $1.83 \times 10^{-11}$ & $1.67 \times 10^{-11}$ & 8 \\
\hline & & TANSIG & $3-5-3-1$ & 0.00180 & 0.9739 & $3.44 \times 10^{-11}$ & $1.77 \times 10^{-11}$ & 10 \\
\hline \multirow[t]{2}{*}{ CFBP } & $\mathrm{BR}$ & TANSIG & $3-5-3-1$ & 0.00084 & 0.9809 & $1.66 \times 10^{-11}$ & $1.48 \times 10^{-11}$ & 14 \\
\hline & & TANSIG-LOGSIG-TANSIG & $3-3-3-1$ & 0.00071 & 0.9817 & $1.64 \times 10^{-11}$ & $1.37 \times 10^{-11}$ & 14 \\
\hline
\end{tabular}

Table 6. Best selected topologies including training algorithm, different layers and neurons for FFBP and CFBP for energy consumption of terebinth fruit

\begin{tabular}{|c|c|c|c|c|c|c|c|c|}
\hline Network & $\begin{array}{c}\text { Training } \\
\text { algorithm }\end{array}$ & Threshold function & $\begin{array}{c}\text { Number of } \\
\text { layers } \\
\text { and neurons }\end{array}$ & $M S E$ & $R^{2}$ & $M A E$ & $S D_{\mathrm{MAE}}$ & Epoch \\
\hline \multirow[t]{4}{*}{ FFBP } & $\mathrm{LM}$ & TANSIG & $3-6-4-1$ & 0.00011 & 0.9893 & 90.66 & 84.66 & 12 \\
\hline & & TANSIG-LOGSIG-PURELIN & $3-5-3-1$ & 0.00348 & 0.9601 & 293.06 & 234.66 & 22 \\
\hline & $\mathrm{BR}$ & TANSIG-PURELIN-TANSIG & $3-5-4-1$ & 0.00016 & 0.9835 & 199.68 & 145.39 & 9 \\
\hline & & PURELIN-TANSIG-TANSIG & $3-4-5-1$ & 0.00018 & 0.9876 & 174.35 & 130.09 & 12 \\
\hline \multirow[t]{2}{*}{ CFBP } & $\mathrm{BR}$ & PURELIN-TANSIG-TANSIG & $3-4-4-1$ & 0.00148 & 0.9811 & 183.49 & 169.95 & 107 \\
\hline & & TANSIG-LOGSIG-TANSIG & $3-5-4-1$ & 0.00128 & 0.9815 & 154.02 & 137.71 & 127 \\
\hline
\end{tabular}


Kaveh M., Chayjan R.A., 2014. Prediction of some physical and drying properties of terebinth fruit (Pistacia atlantica L.) using Artificial Neural Networks. Acta Sci. Pol., Technol. Aliment. 13(1), 65-78.

Table 7. Best selected topologies including training algorithm, different layers and neurons for FFBP and CFBP for shrinkage of terebinth fruit

\begin{tabular}{|c|c|c|c|c|c|c|c|c|}
\hline Network & $\begin{array}{l}\text { Training } \\
\text { algorithm }\end{array}$ & Threshold function & $\begin{array}{l}\text { Number of } \\
\text { layers } \\
\text { and neurons }\end{array}$ & $M S E$ & $R^{2}$ & $M A E$ & $S D_{\mathrm{MAE}}$ & Epoch \\
\hline \multirow[t]{4}{*}{ FFBP } & LM & PURELIN-TANSIG-TANSIG & $3-3-4-1$ & 0.00684 & 0.9525 & 0.306 & 0.233 & 16 \\
\hline & & TANSIG-PURELIN-PURELIN & $3-5-5-1$ & 0.00048 & 0.9804 & 0.206 & 0.089 & 8 \\
\hline & $\mathrm{BR}$ & TANSIG & $3-5-3-1$ & 0.00052 & 0.9709 & 0.248 & 0.123 & 11 \\
\hline & & TANSIG-PURELIN-TANSIG & $3-4-4-1$ & 0.00697 & 0.9552 & 0.276 & 0.201 & 11 \\
\hline \multirow[t]{2}{*}{ CFBP } & $\mathrm{BR}$ & TANSIG & $3-5-5-1$ & 0.00174 & 0.9702 & 0.256 & 0.144 & 52 \\
\hline & & PURELIN-TANSIG-TANSIG & $3-4-3-1$ & 0.00707 & 0.9470 & 0.309 & 0.277 & 9 \\
\hline
\end{tabular}

Table 8. Best selected topologies including training algorithm, different layers and neurons for FFBP and CFBP for drying rate $(D R)$ and moisture ratio $(M R)$ of terebinth fruit

\begin{tabular}{|c|c|c|c|c|c|c|c|c|c|}
\hline Network & $\begin{array}{l}\text { Training } \\
\text { algorithm }\end{array}$ & Threshold function & $\begin{array}{c}\text { Number of } \\
\text { layers } \\
\text { and neurons }\end{array}$ & $M S E$ & $R^{2}(D R)$ & $R^{2}(M R)$ & $\begin{array}{l}M A E \\
(D R)\end{array}$ & $\begin{array}{l}M A E \\
(M R)\end{array}$ & Epoch \\
\hline \multirow[t]{4}{*}{ FFBP } & LM & LOGSIG-TANSIG-PURELIN & $4-5-3-2$ & 0.00039 & 0.9666 & 0.9921 & 0.0005 & 0.0152 & 39 \\
\hline & & TANSIG-LOGSIG-TANSIG & $4-5-5-2$ & 0.00002 & 0.9678 & 0.9945 & 0.0005 & 0.0136 & 121 \\
\hline & $\mathrm{BR}$ & LOGSIG-PURELIN-TANSIG & $4-6-6-2$ & 0.00075 & 0.9565 & 0.9889 & 0.0006 & 0.0211 & 72 \\
\hline & & TANSIG-TANSIG-PURELIN & $4-3-3-2$ & 0.00052 & 0.9528 & 0.9900 & 0.0006 & 0.0188 & 89 \\
\hline \multirow[t]{4}{*}{ CFBP } & LM & TANSIG-PURELIN-TANSIG & $4-4-5-2$ & 0.00158 & 0.9494 & 0.9871 & 0.0006 & 0.0210 & 31 \\
\hline & & TANSIG & $4-4-4-2$ & 0.00071 & 0.9515 & 0.9899 & 0.0006 & 0.0196 & 32 \\
\hline & $\mathrm{BR}$ & LOGSIG-TANSIG-PURELIN & $4-5-5-2$ & 0.00069 & 0.9627 & 0.9897 & 0.0005 & 0.0186 & 31 \\
\hline & & TANSIG-PURELIN-PURELIN & $4-5-3-2$ & 0.00014 & 0.9652 & 0.9945 & 0.0006 & 0.0148 & 151 \\
\hline
\end{tabular}

If the hidden neurons number used is not sufficient, the network may generalize the relationship well but may not have enough power to generalize the patterns well with an acceptable precision.

Tables 5 to 8 shows the mean values of MSE, MAE value, and $R^{2}$ of the final ANN model to predict each of the moisture diffusivity, energy consumption, shrinkage, drying rate and moisture ratio out-put parameters.

The best result for predication moisture diffusivity belongs to FFBP network, 3-6-3-1 topology and TANSIG threshold function with LM algorithm in the first strategy. This structure generated $M S E=0.00032, M A E=1.64 \cdot 10^{-11}, R^{2}=0.9857$ and
$S D_{\mathrm{MAE}}=1.15 \cdot 10^{-11}$ converged in 11 epochs (Table 5). The best results for predication energy consumption at belonged FFBP network to 3-6-4-1 topology and TANSIG threshold function with LM algorithm in the first strategy. This structure generated $M S E=$ $0.00011, M A E=90.66, R^{2}=0.9893$ and $S D_{\mathrm{MAE}}=$ 84.66 converged in 12 epochs (Table 6). The best results for predication shrinkage belongs to FFBP network, 3-5-5-1 topology and TANSIG threshold function with LM algorithm in the first strategy. This structure generated $M S E=0.00048, M A E=0.206$, $R^{2}=0.9804$ and $S D_{\mathrm{MAE}}=0.0891$ converged in 105 epochs (Table 7). 
Figure 5 compares the predicted values with the desired output values on a plot of moisture diffusivity, energy consumption and shrinkage for kinetics analysis of infrared-fluidized bed drying of terebinth fruit using the optimal static ANN.
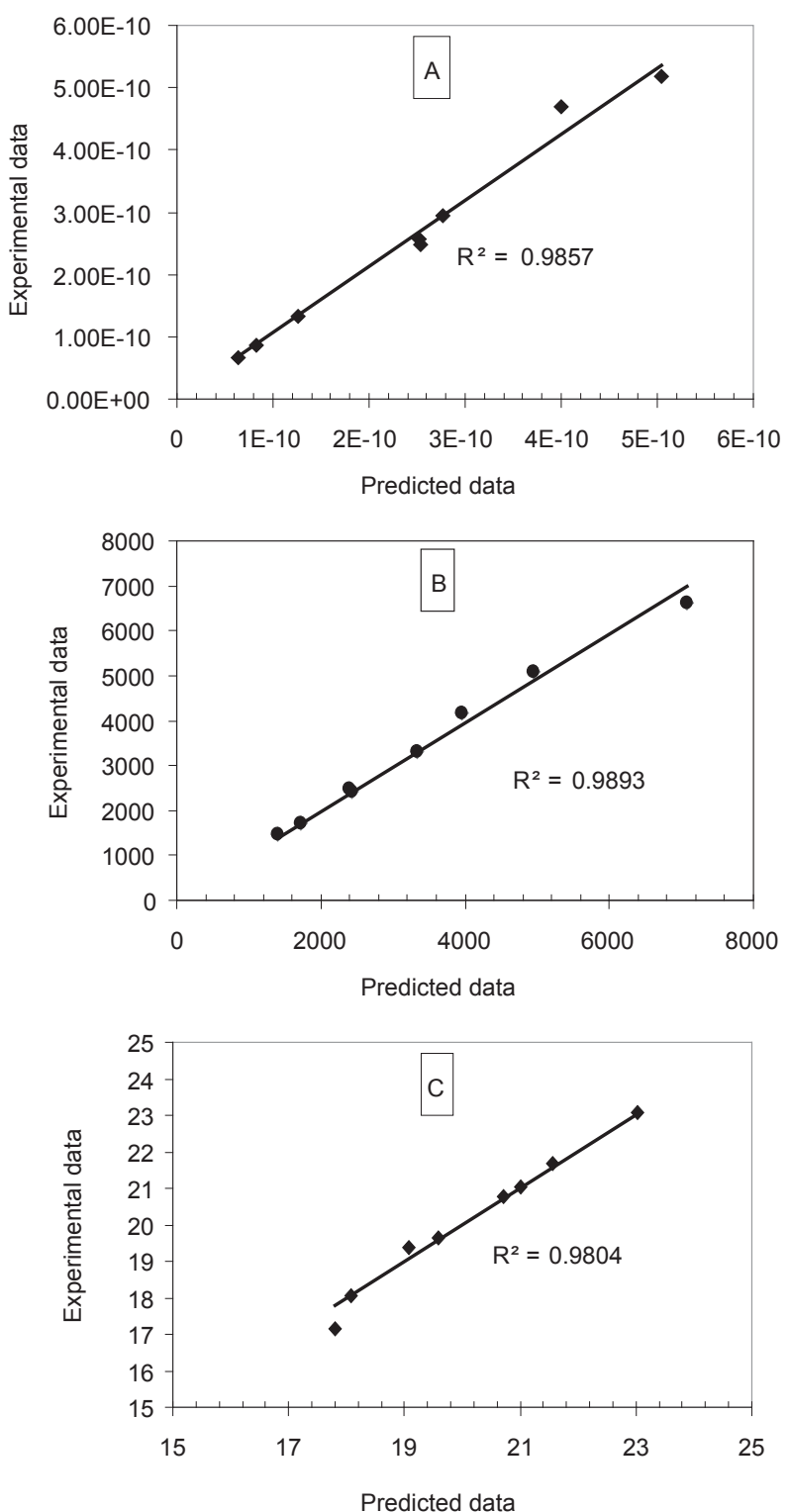

Fig. 5. Predicted values of(A) moisture diffusivity, (B) energy consumption and $(\mathrm{C})$ shrinkage using artificial neural networks versus experimental values for testing data set
The best results for predication drying rate and moisture ratio belonged to FFBP network, 4-5-5-2 topology and TANSIG-LOGSIG-TANSIG threshold function with LM algorithm in the first strategy. This structure generated $M S E=0.00002, M A E=0.0136$, $R^{2}=0.9945$ and $S D_{\mathrm{MAE}}=0.0118$ for moisture ratio and $M A E=0.0005, R^{2}=0.9678$ and $S D_{\mathrm{MAE}}=0.0008$ for drying rate, converged in 121 epochs (Table 8).

Performance of the selected ANNs to predict drying kinetics is shown in Table 8. The ability of selected ANN to predict moisture ratio was better than that for predicting drying rate, due to higher value of $R^{2}$ for moisture ratio in Table 8.

Figure 6 compares the predicted values with the desired output values on a plot of moisture ratio and drying rate for kinetics analyses is infrared fluidized bed drying of terebinth fruit using the optimal static ANN.
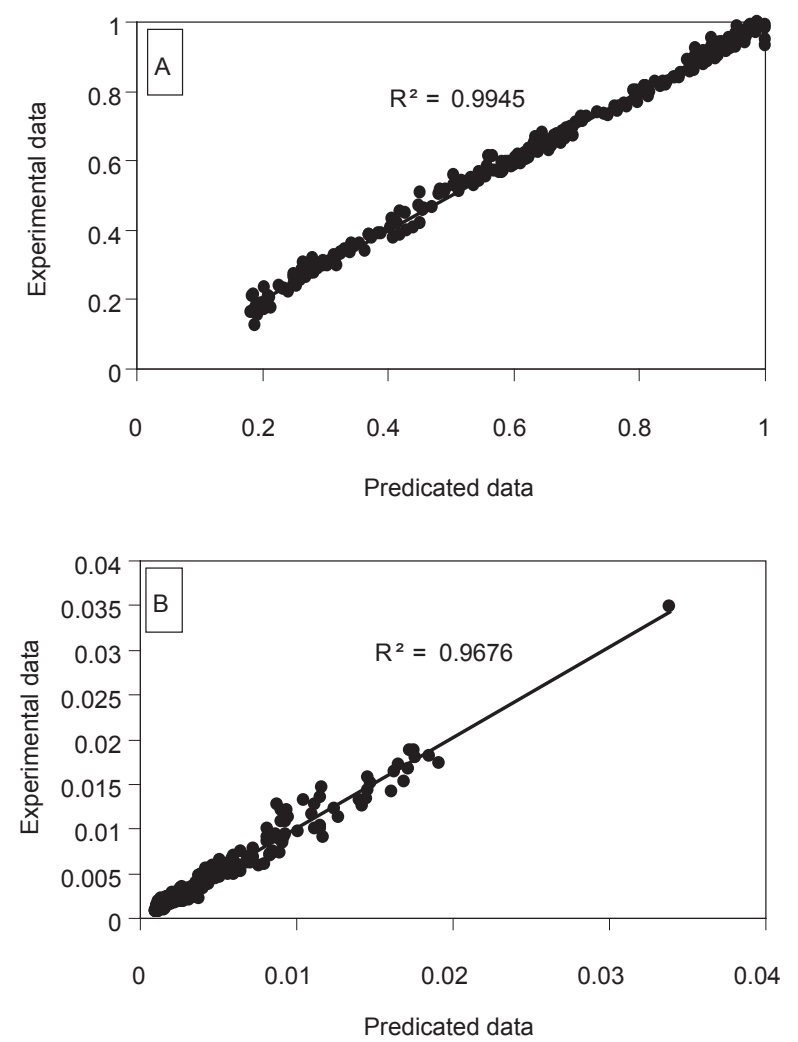

Fig. 6. Predicted values of (A) moisture ratio and (B) drying rate using artificial neural networks versus experimental values for testing data set 
These results imply that the designed ANN model was properly capable of learning the relationship between the input and output parameters. These results also indicated that a properly trained ANN was able to predict simultaneously more than one output, unlike common models where one mathematical model was required for each output (Table 8). The optimized ANN model provided favourable results over the whole set of values for all the dependent variables.

This indicates the fact that the achieved ANN model can assuredly replace the mathematical models for infrared fluidized bed dryer parameters prediction, since it takes acceptable performance using the experimental data and automatically improves itself through learning. In addition, the optimized ANN model has the ability to relearn and improve its performance if new dataset is presented. This provides the gradual possibility of establishment of a unique powerful model which can be of paramount importance in automatic control system.

Figures 5 and 6 showed the testing data points are banded around a $45^{\circ}$ straight line, demonstrating the suitability of the selected static multilayer feed forward ANNs in predicting the kinetics analysis of fluidized bed drying of terebinth fruit. Process simulation and its control in drying technology has always been quite challenging, filed due to the time-varying characteristics and non-linearity of drying phenomena. Therefore, the ANN approach is an alternative to usual methods, which can give a higher estimation precision and make it possible to operate in a broader range.

In mathematical modelling, only one empirical model is required to predict one output, whereas an optimized MLP ANN uses a set of weights for all drying parameters and is able to model simultaneously all outputs together. Empirical models are physically explainable, but interpretation of the MLP ANN structure is difficult. Because ANN has "black box" nature which does not give real information about weighting factors of the components to the operator, although various model comparisons and sensitivity tests may provide information about their physical meanings [Omid et al. 2009].

\section{CONCLUSIONS}

In this study, supervised ANN models were developed to determine the moisture diffusivity, shrinkage, drying rate and moisture ratio performance of terebinth drying process. A multilayer feed forward neural network (FFNN) and casced forward neural network (CFNN) trained by back propagation algorithms was developed to predict the moisture diffusivity, shrinkage, drying rate and moisture ratio based on the three and four variables. It was concluded that the MLP ANN approach for moisture diffusivity, shrinkage, drying rate and moisture ratio prediction of terebinth drying process is capable of yielding good results and can be considered as an attractive alternative to traditional regression models and other related statistical approaches. This approach was able to determine the nonlinear relationship between input and output data supplied to the system during the training phase and on that basis, makes a prediction of what the moisture diffusivity, shrinkage, drying rate and moisture ratio performance would be in any dryer operational condition. The final selected ANN model was able to predict simultaneously the two output parameters (moisture ratio and drying rate) with $M S E=0.00002, R^{2}=$ 0.9678 and 0.9945 , and $M A E=0.0005$ and 0.0136, respectively.

\section{REFERENCES}

Aghbashlo M., Kianmehr M.H., Nazghelichi T., Rafiee S., 2011. Optimization of an artificial neural network topology for predicting drying kinetics of carrot cubes using combined response surface and genetic algorithm. Drying Technol. 29 (7), 770-779.

Aghbashlo M., Mobli H., Rafiee S., Madadlou A., 2012. The use of artificial neural network to predict exergetic performance of spray drying process: A preliminary study. Comput. Electron. Agric. 88, 32-43.

Ahrne L.M., Pereira N.R., Staack N., Floberg P., 2007. Microwave convective drying of plant foods at constant and variable microwave power. Drying Technol. 25 (7), 1149-1153.

Amiri Chayjan R., Kaveh M., 2013. Physical parameters and kinetic modeling of fix and fluid bed drying of terebinth seeds. J. Food Process. Preserv. doi:10.1111/ jfpp. 12092 [in press]. 
Amiri Chayjan R., Amiri Parian J., Esns-Ashari M., 2011. Modeling of moisture diffusivity, activation energy and specific energy consumption of high moisture corn in a fixed and fluidized bed convective dryer. Spanish J. Agric. Res. 9 (1), 28-40.

Amiri Chayjan R., Salari K., Barikloo H., 2012 a. Modelling moisture diffusivity of pomegranate seed cultivars under fixed, semi fluidized and fluidized bed using mathematical and neural network methods. Acta Sci. Pol., Technol. Aliment. 11 (2), 137-149.

Amiri Chayjan R., Alizade H.H.A., Shadidi B., 2012 b. Modelling of some pistachio drying characteristics in fix, semi fluid and fluid bed dryer. Agric. Eng. Int. CIGR J. 14 (2), 143-154.

Chegini G.R., Khazaei J., Ghobadian B., Goudarzi A.M., 2008. Prediction of process and product parameters in an orange juice spray dryer using artificial neural networks. J. Food Eng. 84 (4), 534-543.

Chen D., Zheng Y., Zhu X., 2012. Determination of effective moisture diffusivity and drying kinetics for poplar sawdust by thermogravimetric analysis under isothermal condition. Biores. Technol. 107, 451-455.

Das I., Das S.K., Bal S., 2009. Drying kinetics of high moisture paddy undergoing vibration-assisted infrared (IR) drying. J. Food Eng. 95, 166-171.

Demuth H., Beale M., Hagan M., 2007. Neural network toolbox 5. The MathWorks, Natick, MA, USA.

Dissa A.O., Desmorieux H., Savadogo P.W., Segda B.G., Koulidiati J., 2010. Shrinkage, porosity and density behaviour during convective drying of spirulina. J. Food Eng. 97, 410-418.

Dondee S., Meeso N., Soponronnarit S., Siriamornpun S., 2011. Reducing cracking and breakage of soybean grains under combined near-infrared radiation and fluidized-bed drying. J. Food Eng. 104, 6-13.

Doymaz I., 2005. Influence of pretreatment solution on the drying of sour-cherry. J. Food Eng. 78, 591-596.

Erenturk S., Erenturk K., 2007. Comparison of genetic algorithm and neural network approaches for the drying process of carrot. J. Food Eng. 78 (3), 905-912.

Jha G.K., 2007. Artificial Neural Networks. [online], http:// www.iasri.res.in/ebook/EB_SMAR/e-book_pdf\%20 files/Manual\%20IV/3-ANN.pdf.

Khir R., Pan Z., Salim A., Hartsough B.R., Mohamed S., 2011 Moisture diffusivity of rough rice under infrared radiation drying. LWT-Food Sci. Technol. 44, 1126-1132.

Khoshhal A., Alizadeh Dakhel A., Etemad A., Zereshki S., 2010. Artificial neural network of apple drying process. J Food Process Eng. 33 (1), 298-313.
Kurozawa L.E., Hubinger M.D., Park K.J., 2012. Glass transition phenomenon on shrinkage of papaya during convective drying. J. Food Eng. 108, 43-50.

Madadlou A., Emam-Djomeh Z., Mousavi M.E., Ehsani M., Javanmard M., Sheehan D., 2009. Response surface optimization of an artificial neural network for predicting the size of re-assembled casein micelles. Comput. Electron. Agric. 68 (2), 216-221.

Markowski M., Białobrzewski I., Modrzewska A., 2010. Kinetics of spouted-bed drying of barley: Diffusivities for sphere and ellipsoid. J. Food Eng. 96, 380-387.

Meeso N. 2008. Far-infrared heating in paddy drying process. In New food engineering research trends. Ed. A.P. Urwaye. Nova Sci. Publ. New York, 225-256.

Menlik T., Özdemir M.B., Kirmaci V., 2010. Determination of freeze-drying behaviors of apples by artificial neural network. Expert Syst. Applic. 37, 7669-7677.

Mohebbi M., Shahidi F., Fathi M., Ehtiati A., Noshad M., 2011. Prediction of moisture content in pre-osmosed and ultrasounded dried banana using genetic algorithm and neural network. Food Bioprod. Process. 89, 362-366.

Mundada M., Hathan B.S, Maske S., 2010. Convective dehydration kinetics of osmotically pretreated pomegranate arils. Biosyst. Eng. 107, 307-316.

Niamnuy C., Nachaisin M., Poomsa-ad N., Devahastin S., 2012. Kinetic modelling of drying and conversion/degradation of isoflavones during infrared drying of soybean. Food Chem. 133, 946-952.

Nowacka M., Wiktor A., Sledz M., Jurek N., Witrowa-Rajchert M.D., 2012. Drying of ultrasound pretreated apple and its selected physical properties. J. Food Eng. 113, 427-433.

Nuthong P., Achariyaviriya A., Namsanguan K., Achariyaviriya S., 2011. Kinetics and modeling of whole longan with combined infrared and hot air. J. Food Eng. 102, 233-239.

Omid M., Baharlooei A., Ahmadi H., 2009. Modeling drying kinetics of pistachio nuts with multilayer feed-forward neural network. Drying Technol. 27(10), 1069-1077.

Ponkham K., Meeso N., Soponronnarit S., Siriamornpun S., 2012. Modeling of combined far-infrared radiation and air drying of a ring shaped-pineapple with/without shrinkage. Food Bioprod. Process. 90, 155-164.

Ruiz Celma A., López-Rodríguez F., Cuadros Blázquez F., 2009. Experimental modelling of infrared drying of industrial grape by-products. Food Bioprod. Process. 87, 247-253.

Ruiz Celma A., Cuadros F., López-Rodríguez F., 2012. Convective drying characteristics of sludge from treatment 
Kaveh M., Chayjan R.A., 2014. Prediction of some physical and drying properties of terebinth fruit (Pistacia atlantica L.) using Artificial Neural Networks. Acta Sci. Pol., Technol. Aliment. 13(1), 65-78.

plants in tomato processing industries. Food Bioprod. Process. 90, 224-234.

Siriamornpun S., Kaisoon O., Meeso N., 2012. Changes in colour, antioxidant activities and carotenoids (lycopene, b-carotene, lutein) of marigold flower (Tagetes erec$t a \mathrm{~L}$.) resulting from different drying processes. J. Funct. Foods 4, 757-766.

Thuwapanichayanan R., Prachayawarakorn S., Kunwisawa J., Soponronnarit S., 2011. Determination of effective moisture diffusivity and assessment of quality attributes of banana slices during drying. LWT-Food Sci. Technol. 44, 1502-1510.

Xiao H.W., Pang C.L., Wang L.H., Bai J.W., Yang W.X., Gao Z.J., 2010. Drying kinetics and quality of Monukka seedless grapes dried in an air-impingement jet dryer. Biosyst. Eng. 105, 233-240.

Received - Przyjęto: 25.06.2013

For citation - Do cytowania

Kaveh M., Chayjan R.A., 2014. Prediction of some physical and drying properties of terebinth fruit (Pistacia atlantica L.) using Artificial Neural Networks. Acta Sci. Pol., Technol. Aliment. 13(1), 65-78. 